\title{
LITERASI MEDIA BAGI GURU PAUD DI KECAMATAN CICALENGKA
}

\author{
Saepudin, E., Damayani, N.A., dan Sukaesih \\ Universitas Padjadjaran \\ E-mail: encang@unpad.ac.id
}

\begin{abstract}
ABSTRAK
Pengabdian Kepada Masyarakat 2016 ini berjudul Pelatihan Literasi Informasi Media Pembelajaran Bagi Guru PAUD di Kecamatan Tanjungsari. Kegiatan Pelatihan literasi media ini bertujuan untuk menambah wawasan dan memberikan pengetahuan terbaru tentang pemanfaatan media sebagai sumber belajar bagi para guru dan siswa, terutama bagi guru yang harus membuat sebuah kegiatan pengajaran kepada siswanya. Kegiatan Pengabdian Kepada Masyarakat dilaksanakan bekerja sama dengan Pihak UPTD Dinas Pendidikan Kecamatan Cicalengka Kabupaten Bandung. Pelaksanaan Kegiatan Pengabdian Kepada Masyarakat yaitu pada tanggal 1 September 2016. Materi utama yang disampaikan dalam pelatihan ini yakni literasi media dan langkah-langkah membangun literasi media. Metode yang digunakan adalah ceramah, diskusi, dan simulasi. Hasil yang dicapai menujukan adanya peningkatan pengetahuan dan keterampilan dari seluruh peserta. Hal ini terlihat dari hasil pretest dan posttest yang dilaksanakan. Jumlah peserta mencapai target, dengan animo peserta cukup tinggi menghasilkan diskusi mengalir dan simulasi dilaksanakan dengan sangat antusias. Dari hasil refleksi kegiatan, diperoleh kesimpulan bahwa peserta memahami dan mampu membuat rancangan pembelajaran berbasis literasi media.
\end{abstract}

Kata kunci: literasi, literasi informasi, literasi media, media, media pembelajaran.

\section{ABSTRACT}

This 2016 Community Services is entitled Learning Media Information Literacy Training for Teachers of PAUD in District Cicalengka. Media literacy training activities aim to broaden and provide the latest knowledge about the use of media as a source of learning for teachers and students, especially for teachers who have to make teachingactivities for their students. The community service activities were carried out in collaboration with the UPTD (Department of Education of Subdistrict) Bandung District of Cicalengka. The Community Services Activity was conducted on 1 September 2016. The main materials presented were the media literacy training and steps to build media literacy. The methods used were lectures, discussions, and simulation. The result showed an increase in knowledge and skills of all participants. This was shown from the results of pretest and posttest conducted. The number of participants achieving the target, with the participants'high interest had generated discussion flowed, and simulations were carried out with great enthusiasm. From the results of activities reflection, it was concluded that participants understood and were able to create media literacy based learning design.

Keywords: literacy, information literacy, media literacy, media, instructional media.

\section{PENDAHULUAN}

Pendidikan prasekolah dinilai menjadi pendidikan yang dapat mendasari pendidikan selanjutnya. Nilainilai penting dalam kehidupan dapat tertanam pada anak usia dini. Sehingga pendidikan pada usia usia dini tidak bisa dilaksanakan secara asal-asalan. Hal ini mengingat pendidikan tidak dapat dilaksanakan secara mendadak ketika anak sudah besar. Justru ketika masih kecil itulah pendidikan perlu direncanakan sebaik mungkin. karena pendidikan pada masa itu merupakan proses meletakkan dasar atau pondasi. Pendidikan lanjutan tinggal meneruskan apa yang telah diperoleh ketika kecil. Pendidikan dalam bentuk pembiasaan, penanaman nilai-nilai, serta aspek-aspek dasar terjadi ketika anak-anak masih kecil. Untuk itulah setiap lembaga pendidikan pra sekolah harus memiliki dasardasar seperti itu secara kokoh dan komprehensif.

Usia di bawah lima tahun (balita) adalah usia yang paling kritis atau paling menentukan dalam pembentukan karakter dan kepribadian seseorang. Termasuk juga pengembangan intelegensi anak hampir seluruhnya terjadi pada usia di bawah lima tahun. Kalau seseorang sudah terlanjur menjadi pencuri atau penjahat, maka pendidikan Universitas bagi orang tersebut boleh dikatakan tidak berarti apa-apa. Sebagaimana halnya sebatang pohon bambu, setelah tua susah dibengkokkan.

Anak-anak pada usia di bawah lima tahun memiliki intelegensi laten (potential intelegence) yang luar biasa. Namun, pada umumnya para orang tua dan guru hanya bisa mengajarkan sedikit hal pada anak-anak. Sesungguhnya anak-anak usia dini tidak "complicated" 'ruwet' dalam belajar, tetapi orang tua atau guru yang bermasalah. Pada umumnya kita selalu menyalahkan anak-anak apabila tingkah laku mereka tidak seperti yang kita inginkan. Hal ini lebih banyak disebabkan 
karena kurangnya pengetahuan dan pemahaman kita terhadap perkembangan jiwa anak, sehingga kita sering memperlakukannya dengan tidak/kurang tepat.

Pendidikan yang dilandasi dengan kreativitas adalah strategi yang cocok untuk anak usia dini. Meskipun usianya sudah cukup tua, teori-teori belajar yang dikemukakan oleh para ahli pendidikan pada awal abad ke-20 masih sangat layak diberlakukan. Namun, untuk masa sekarang yang lingkungannya menuntut gerak dan aktivitas yang lebih responsif, teori-teori tersebut membutuhkan modifikasi sesuai dengan konteks di mana anak belajar.

Pada saat ini, perkembangan teknologi komunikasi dan informasi sudah tidak bisa dibendung. Teknologi ini menerpa seluruh lapisan masyarakat tidak terkecuali anak-anak. Dalam kehidupan sehari-hari anak-anak selalu bersentuhan dengan media TV, Radio, dan Internet. Media massa terutama TV sudah tidak bias lepas dari kehidupan anak-anak. Terkadang sambil minum, makan, bahkan belajar anak-anak selalu berdekatan dengan media TV.

Kehadiran media massa terutama media TV telah memberi banyak perubahan dalam kehidupan bermasyarakat, berbangsa, dan cara kita beragama atau mengamalkan ajaran agama yang kita anut. Seluruh lapisan masyarakat terkena perubahan, termasuk anak usia Dini. Hal ini disebabkan oleh daya tarik media yang begitu kuat, program yang terencana dengan kombinasi audio dan visual yang menarik. Kompetisi yang sangat ketat membuat media massa saling berebut pemirsa, sehingga sering kali terjadi pertimbangan profit menjadi nomor satu bila dibandingkan dengan faktor edukasi isi siaran.

Literasi media adalah kemampuan untuk memahami, menganalisis dan mendekonstruksi pencitraan media. Kemampuan untuk melakukan ini ditujukan agar pemirsa sebagai konsumen media massa - termasuk anak-anakmenjadi sadar bagaimana cara media dikonstruksi/ dibuat dan diakses. Literasi media harus dikembangkan dalam masyarakat kita karena tidak seorang pun manusia dilahirkan ke dunia ini dalam kondisi telah melek media, "No one is born media literate".

Oleh karena itu, literasi informasi terutama literasi media sangat dibutuhkan untuk memiliki kemampuan dalam menyeleksi informasi yang terkandung atau yang disediakan oleh media tersebut. Secara sederhana literasi media adalah sebuah keterampilan yang diperlukan guna berinternaksi secara pintar dengan media, khususnya televisi. Hal ini menjadi penting, agar kita tidak terkena dampak negatif televisi. Literasi media mengajak kita mengevaluasi tayangan dan berpikir kritis tentang pesan yang disampaikan televisi. Apakah pantas, logis, dan bermoral atau tidak.
Pada kurikulum 2013 telah memasukan kemampuan pemilihian media sebagai kemampuan yang harus dimiliki oleh para guru dan siswa. literasi media telah diimplementasikan dalam kurikulum 2013 ini. Berbagai informasi dengan berbagai format menerpa setiap individu dalam setiap waktu. Bahkan dalam satu waktu setiap orang dapat memperoleh informasi yang tak terbatas. Untuk menyikapinya ledakan informasi yang saat ini terus berkembang kita memerlukan sebuah strategi literasi yaitu information literacy skills. Strategi ini dimaknai sebagai kemampuan untuk mengenali adanya kebutuhan informasi dan kemampuan untuk menempatkan, mengevaluasi, dan menggunakan informasi dengan efektif.

Literasi informasi diperlukan untuk meningkatkan kualitas diri dalam rangka belajar seumur hidup. Ketika seseorang bermaksud meningkatkan taraf hidupnya, maka dia memerlukan sesuatu yang lebih dari dirinya yaitu perkembangan diri, baik ketrampilan, pendidikan atau kinerja yang lebih baik. Dalam proses belajar itu pun memerlukan informasi yang tepat dan benar. Bagi masyarakat kemampuan ini akan menentukan banyaknya informasi yang dapat diserap, dan lebih dari itu masyarakat akan semakin mampu menyelesaikan masalah secara kritis, logis, dan tidak mudah diperdaya oleh informasi yang diterimanya tanpa evaluasi.

Mengajarkan literasi media pada anak-anak usia dini sangat strategis, karena mereka adalah anak yang tengah tumbuh dengan pesat secara biologis maupun psikis. Mereka suka meniru, tanpa berupaya mengkritisinya terlebih dahulu. Orang tua dan guru merupakan pihak yang paling dekat dengan anak. Oleh karena itu, sesuatu yang sangat wajib bagi orang tua dan guru untuk selalu mendampingi dan membina anak-anak dalam berinteraksi dengan media. Hal pokok yang harus difahami oleh para guru, bahwa anak-anak seumuran Dini lebih sering patuh kepada gurunya bila dinasihati.

Oleh karena itu, guru PAUD dapat menyisipkan materi literasi media saat mengajar di kelas dengan model penayangan audio visual film kartun yang banyak digemari anak-anak, Setelah penayangan film dilanjutkan dengan dialog kepada murid mengenai isi tayangan tersebut. Dalam proses dialog tersebut peril dijelaskan kepada para siswa mengenai kandungan informasi dalam film tersebut terutama pesan-pesan moral yang ada di dalamnya. Jadi tidak perlu kita menyalahkan media begitu saja karena itu tidak adil. Media bisa bermanfaat (bahkan sangat banyak manfaatnya, seperti untuk pendidikan).

Berdasarkan hal tersebut dapat dikatakan bahwa Tradisi literasi merupakan kemampuan seseorang dalam menggunakan informasi tertulis atau cetak untuk mengembangkan pengetahuan, sehingga mendatangkan manfaat 
bagi masyarakat. General Director UNESCO, Koiichiro Matsuura menjelaskan bahwa literasi lebih dari sekadar membaca dan menulis. Melainkan juga mencakup bagaimana kita berkomunikasi dalam masyarakat. Karena literasi berarti juga praktik dan hubungan sosial yang terkait dengan pengetahuan, bahasa dan budaya.

Berbicara tentang literasi informasi tidak terlepas dari 3 hal yaitu:

1. budaya melek huruf; budaya melek huruf menimbulkan efektivitas dan efesiensi penggunaan simbolsimbol tulisan. Masyarakat dapat meng-akumulasi sebuah body of knowledge (bangunan pengetahuan) yang lebih permanen dan mewariskan pengetahuan tersebut ke generasi berikutnya,

2. revolusi Gutenberg; dengan ditemukannya mesin cetak oleh Gutenberg pada tahun 1946, maka proses penyampaian informasi menjadi lebih cepat. Informasi menjadi cepat tersebar ke berbagai wilayah yang mengakibatkan kemajuan di berbagai bidang,

3. teknologi komunikasi; setiap kemajuan teknologi berpengaruh pada kebudayaan. Munculnya majalah, surat kabar, televisi, radio dan internet telah menciptakan budaya yang berbeda dan beragam di masing-masing daerah.

Berangkat dari penjelasan di atas, tradisi literasi harus benar-benar lekat dalam kehidupan masyarakat. Itu kalau kita ingin mewujudkan kota yang maju dengan masyarakat yang cerdas karena tingkat literasi yang rendah berkaitan erat dengan tingginya tingkat drop out sekolah, kemiskinan, dan pengangguran. (Wagner: 2000)

Ketiga aspek tersebut adalah sebagian dari indikator rendahnya indeks pembangunan manusia. Maka apabila masyarakat tidak siap menerima individu-individu masyarakat yang rendah kualitasnya, mari kita upayakan sedari dini nuansa kondusif menuju terciptanya budaya keilmuan dalam kehidupan masyarakat yaitu menciptakan tradisi literasi.

Yang dimaksud dengan literasi media adalah "ability to access, analize, evaluate and communicate the content of media messages". Literasi media juga bermakna kemampuan untuk memahami, menganalisis dan mendekonstruksi pencitraan media. Kemampuan untuk melakukan ini ditujukan agar pemirsa sebagai konsumen media massa termasuk anak-anak menjadi sadar atau melek tentang cara media dikonstruksi/dibuat dan diakses.

Literasi media juga disebut dengan melek media. Seiring perjalanan waktu, arus informasi semakin mudah disebarkan. Begitu pula teknologi yang meng- hantarkan informasi kian cepat perkembangannya. Publik sebagai sasaran atau target penyediaan informasi tentu sangat diuntungkan dengan perkembangan tekno-logi komunikasi masa kini. Namun, di lain pihak tidak sedikit perusahaan media yang gencar melakukan penyediaan informasi sebagai bisnis menggiurkan yang akhirnya menciptakan apa yang disebut sebagai industri media.

Secara umum prinsip bisnis media atau industri media ini lebih diarahkan pada arus utama (mainstream) bagaimana mendapatkan uang atau keuntungan bagi perusahaan. Prinsip tersebut terkadang tanpa mempertimbangkan kepentingan publik. Akibat dari arus yang kuat atas kepentingan uang ini, media mainstream menjadi tidak independen, objektif dan akurat, dalam arti lain menjadi masalah baru bagi publik yang seharusnya mendapatkan informasi yang sebenarbenarnya dan sekaligus positif bagi masyarakat.

Masalah-masalah tersebut diantaranya: tayangan (atau bacaan) yang diskriminatif terhadap ras, gender, dan agama, termasuk masalah anak dan hak asasi manusia yang terabaikan. Efeknya bagi publik adalah ketidakberimbangan informasi dan pendidikan mengenai kemanusiaan, seakanakan tidak ada rasa peduli pada lingkungan. Informasi yang didapat publik dari industri media sudah didominasi kepentingan komersil sehingga menjadi "tidak ramah publik". Implikasi permainan pemilik modal industri pada akhirnya membuat publik tidak mempunyai ruang untuk berpartisipasi dan mencari informasi yang benar-benar mereka butuhkan.

Kategori informasi yang dibutuhkan oleh masyarakat memang beragam, dengan demikian tidaklah mudah bagi media untuk memberi sajian informasi/hiburan yang bisa memuaskan seluruh pelanggannya. Sebab definisi kebutuhan ini tidaklah sama antara pemirsa satu dengan lainnya. Namun, setidaknya perlu diketahui bahwa setiap media penyiaran pasti memiliki segmentasi tertentu.

Oleh karena itu, merekalah yang harus menjadi fokus pelayanan media. Kebutuhan kelompok inilah yang perlu dipahami, termasuk tren perubahan gaya hidup mereka. Kerangka berpikir semacam inilah yang dibutuhkan dalam upaya membangun pemantauan serta pengendalian yang konstruktif, sistematis dan proaktif terhadap fenomena industri media yang ada di negara kita. Harapan dari kerangka berpikir tersebut adalah dapat memberikan counter dan himbauan kepada industri media serta membangun kesadaran kritis masyarakat luas serta lebih selektif memilih informasi yang tersedia.

Mengapa literasi media harus dikembangkan? Paling tidak perlu dipahami bahwa tidak seorangpun dilahirkan ke dunia ini dalam kondisi melek media. No one is born media literate. Bahkan dalam proses hidup 
manusia -lahir, tumbuh menjadi anak, lalu remaja dan dewasa, kemudian tua dan pada akhirnya meninggal dunia-sangat sulit untuk mencapai literasi media yang komprehensif. Hal ini disebabkan pengetahuan manusia tentang media dan juga dunia nyata akan membentuk cara pandang untuk memahami media.

Tujuan dari melek media/literasi media adalah: (1) membantu orang mengembangkan pemahaman yang lebih baik. (2) membantu mereka untuk dapat mengendalikan pengaruh media dalam kehidupan seharihari. (3) pengendalian dimulai dengan kemampuan untuk mengetahui perbedaan antara pesan media yang dapat meningkatkan kualitas hidup seseorang dengan pesan media yang "merusak."

\section{METODE}

Kegiatan pelatihan sebagai sebuah kegiatan instruksional/ pengajaran dapat menggunakan berbagai metode yang ada. Menurut Syah (2002 : 202) bahwa "Metode pengajaran dapat berbentuk ceramah, demonstrasi, diskusi serta praktek yang bertujuan untuk memberikan pemahaman pengetahuan, pemahaman aplikasi, dan pemahaman analisis, sintesis, serta evaluasi. Dalam kegiatan pelatihan ini metode yang digunakan yaitu metode ceramah, diskusi, demonstrasi, dan praktek langsung dalam mengetahui, memahami, dan mempraktikkan proses pencarian informasi sebagai salah satu bentuk literasi informasi.

Metode ceramah merupakan metode yang sampai saat ini sering digunakan oleh setiap guru atau instruktur. Hal ini selain disebabkan oleh beberapa pertimbangan tertentu, juga adanya faktor kebiasaan baik dari guru atau pun siswa. Sedangkan metode demonstarsi merupakan metode yang sangat efektif, sebab membantu peserta didik untuk mencari jawaban dengan usaha sendiri berdasarkan fakta atau data yang benar. Metode demonstrasi merupakan metode penyajian pelatihan dengan memperagakan dan mempertunjukkan kepada peserta tentang suatu proses, situasi atau benda tertentu, baik sebenarnya atau hanya sekadar tiruan. dengan memperagakan dan mempertunjukkan kepada peserta pelatihan tentang suatu proses, situasi atau benda tertentu, baik sebenarnya atau hanya sekadar tiruan.

\section{HASIL DAN PEMBAHASAN}

Dalam beberapa tahun terakhir ini terdapat kecenderungan baru di masyarakat Indonesia. Hal tersebut adalah memasukkan anak-anaknya sedini mungkin ke Lembaga Pendidikan Playgroup dan Taman KanakKanak. Taman kanak-kanak tersebut menawarkan konsep pendidikan yang beraneka ragam. Perkembangan baru ini sangat menarik, selain semakin memacu Lembaga Pendidikan Playgroup dan Taman Kanak-Kanak untuk meningkatkan kualitas penyelenggaraan pendidikannya, sehingga memberikan konstribusi yang signifikan bagi dunia pendidikan negeri ini, juga akan membawa implikasi bagi masa depan umat dan bangsa pada khususnya berkenaan dengan pengembangan sumber daya manusia.

Fenomena ini memang menunjukkan bahwa semakin baik tingkat kesadaran akan pendidikan. Namun, di balik itu terdapat hal-hal yang memprihatinkan dimana seringkali pendidikan yang diberikan terlalu sarat dengan hal-hal yang bersifat akademis dan cenderung melupakan jati diri pendidikan prasekolah yang semestinya, serta seringkali kurang memperhatikan tumbuh kembang anak. Dapat dibayangkan apabila pendidikan pra sekolah terlalu mementingkan aspek kognitif dibanding aspekaspek yang lainnya maka masa kanak-kanak mereka menjadi muram dikarenakan kehilangan modal belajar yang berupa positive mental, global learning, happy learning, dan positive supporting yang mengagumkan.

Untuk menciptakan suasana belajar yang menyenangkan tetapi sarat dengan pembinaan terhadap anak prasekolah maka para guru perlu memiliki kemampuan untuk bercerita/ mendongeng. Bahkan ada suatu ungkapan yang berbunyi "Seorang Guru yang tidak bisa bercerita, ibarat orang yang hidup tanpa kepala". Betapa tidak, bagi para pengasuh anak-anak (guru, tutor) keahian bercerita merupakan salah satu kemampuan yang wajib dikuasai. Melalui metode bercerita inilah para pengasuh mampu menularkan pengetahuan dan menanamkan nilai budi pekerti luhur secara efektif, dan anak-anak menerimanya dengan senang hati

Namun kenyataannya, materi literasi media masih sangat jarang dilakukan di berbagai lembaga pengelola PAUD yang ada di Kecamatan Cicalengka. Salah satu hambatan yang sangat besar dari para guru PAUD adalah kurangnya pemahaman mengenai literasi serta masih adanya rasa kurang percaya diri dari para guru PAUD untuk melakukan praktek literasi media. Padahal lembaga PAUD di Kecamatan Cicalengka ini cukup beasr yakni terdiri atas 40 lemaga Paud. Melihat situasi di atas, maka diperlukan peningkatan pengetahuan, pemahaman, keahlian dan keterampilan para Guru PAUD se-Kecamatan Cicalengka mengenai Literasi media. Diharapkan dengan pelaksanaan pelatihan ini akan diperoleh hasil yang lebih maksimal.

Untuk itu, Tim Pengabdian Masyarakat yang telah kami bentuk berusaha untuk memberikan bantuan pendidikan berupa peningkatan pengetahuan, pemahaman, keahlian dan keterampilan para Guru PAUD se-Kecamatan 
Cicalengka mengenai Literasi media, dan diharapkan pula para guru yang mengikuti kegiatan ini dapat membantu mereka dalam melakukan aktivitas bercerita di lembaga pendidikannya masing-masing.

Kegiatan Pengabdian Kepada Masyarakat ini dilaksanakan dalam bentuk pelatihan mengenai Literasi media bagi para guru Paud di Kecamatan Cicalengka Kabupaten Bandung. Tahapan kegiatan pengabdian kepada masyarakat ini yakni tahap persiapa, tahap pelaksanaan, dan tahap penyusunan laporan/ evaluasi.

Tahapan persiapan terdiri dari langkah kegiatan sebagai berikut menyusun tim pelaksana pengabdian kepada masyarakat, menyusun usulan kegiatan pengabdian kepada masyarakat, merumuskan langkah-langkah kegiatan pengabdian kepada masyarakat, merumuskan materi pelatihan pkm, menentukan metode pelaksanaan pengabdian kepada masyarakat, mengumpulkan bahan materi PKM, dan menentukan metode pelaksanaan pengabdian kepada masyarakat.

Tahapan pelaksanaan terdiri dari kegaiatan sebagai berikut penjajakan awal ke lokasi pengabdian kepada masyarakat, Merumuskan perijinan pelaksanaan kegiatan pengabdian kepada masyarakat dari pemerintah setempat, menentukan khalayak sasaran kegiatan pengabdian kepada masyarakat, menentukan waktu pelaksanaan pengabdian kepada masyarakat, sosialisasi kegiatan kepada khalayak sasaran, pelaksanaan kegiatan pengabdian kepada masyarakat, dan evaluasi pelaksanaan kegiatan pengabdian kepada masyarakat. Tahapan penyusunan laporan terdiri atas kegiatan menyusun data hasil kegiatan dan evalusi, menganalisis data, merekontruksi data, dan menyusun laporan.

Kegiatan pelatihan dilaksanakan bertempat di Paud AZZAHRA Kampung Andir No 85 Rt. 04/12 Desa Cikuya Kecamatn Cicalengka Kabupaten Bandung. Peserta yang hadiri 41 orang dari target 40 orang. Peserta dapat memenuhi target karena pelaksanaan Pengabdian Kepada Masyarakat ini bekerjasama dengan pihak UPTD Kecamatan Cicalengka Kabupaten Bandung dan Himpudi Kecamatan. Pelaksanaan kegiatan ini melalui tiga tahapan dengan tiga pendekatan yang dilakukan, yaitu:

a. metode pengumpulan data awal adalah: Pelaksana kegiatan bersama pihak dinas pendidikan kecamatan, himpaudi kecamatan untuk melakukan pemetaan sosial serta untuk mengetahui khalayak sasaran dan kebutuhan mereka,

b. metode pelaksanaan kegiatan ini secara umum menggunakan pembinaan melalui ceramah secara partisipatif adapun teknik yang dilakukan yakni Diskusi, Ceramah, dan Simulasi, c. metode pengumpulan feed back adalah dengan mengumpulkan kritik dan saran peserta setelah mengikuti kegiatan.

Gambaran pelaksanaan kegiatan pelatiha literasi media bagi guru PAUD di Kecamatan Cicalengka Kabupaten Bandung.

Untuk mengukur keberhasilan program pengabdian kepada masyarakat ini, tim pelaksana melaksanakan test berupa pretest dan posttest. Pretest dilaksanakan pada awal pelaksanaan pelatihan. Hal ini dilakukan untuk mengetahui pemahaman awal para perseta pelatihan mengenai tama yang akan di bahas, sedangkan posttest dilaksanakan diakhir pelaksanaan program. Hal ini dilakukan untuk mengukur ketercapaian tujuan pelatihan. Selain itu, posttest dilaksanakan untuk mengetahui berapa persen dari peserta pelatihan yang mampu menyerap materi selama pelatihan berlangsung.

Materi pretest dan posttest sama yakni mengenai pemahaman peserta tentang konsep literasi informasi, literasi media, kriteria masyarakat literat, peran dan pengaruh media terhadap masyarakat literat, dan membangun program literasi media. Berdasarkan hasil pelaksanaan pretest dan posttest dapat terlihat perubahan yang sangat signifikan mengenai pemahaman dan kemampuan para peserta mengenai literasi media.

Tes dilakukan dalam dua kali yakni diawal pelaksanaan pelatihan/ pretest dan pada menjelang selesai pelatihan/ posttest. Pretest bertujuan untuk mengetahui pemahaman awal para peserta pelatihan mengenai materi yang akan disampaikan. Selain itu, untuk menyamakan persamaan pemahaman antara peserta dengan pemateri tentang awal penyampaian materinya. Sedangkan posttest dilakukan dengan tujuan untuk mengetahui ketercapaian tujuan pelatihan. Dalam hal ini tes ini dilaksanakan untuk mengukur keterserapan materi oleh para peserta pelatihan.

Analisis terhadap hasil tes menunjukkan perubahan yang sangat besar dalam pemahaman para peserta mengenai literasi media. Tes mengenai konsep literasi informasi hasil pretest menunjukkan tidak seorangpun yang memahami tetang literasi informasi sedangkan hasil posttest mencapai 39 orang $(95.12 \%)$. Tabel 2 tentang litersi media hasil pretest menunjukkan hanya 27 orang (65.9\%) yang memahami tetang literasi media sedangkan hasil posttest mencapai 40 orang $(97.36 \%)$.

Tes tentang kriteria masyarakat literat hasil pretest menunjukkan tidak seorangpun yang memahami tetang kriteria masyarakat literat sedangkan hasil posttest mencapai 36 orang $(87.80 \%)$. Tes tentang pengaruh media pada masyarakat literat hasil pretest menunjukkan hanya 28 orang (68.3\%) yang memahami tetang literasi informasi sedangkan hasil posttest mencapai 38 
orang $(92.68 \%)$. Tes tentang melek media hasil pretest menunjukkan hanya 20 orang $(48.8 \%)$ yang pengaruh media pada masyarakat literat sedangkan hasil posttest mencapai 39 orang $(90.24 \%)$.

Tes tentang langkah-langkah membangun literasi media hasil pretest menunjukkan tidak ada satuorang pun $(0 \%)$ yang memahami tetang langkah-langkah membangun literasi media sedangkan hasil posttest mencapai 27 orang $(65.9 \%)$. Tes tentang pertimbangan dalam membangun literasi media hasil pretest menunjukkan tidak seorangpun yang memahami tetang pertimbangan dalam membangun literasi media sedangkan hasil posttest mencapai 30 orang $(73.17 \%)$.

Selain dilaksanakan pretest dan posttest, untuk mengukur keberhasilan program pengabdian kepada masyarakat berikutnya adalah evaluasi kegiatan secara keseluruhan. Evaluasi akhir dari kegiatan pelatihan ini dengan cara penyebarkan angket yang berisi pertanyaan tertutup berkaitan dengan materi yang disampaikan, penyediaan waktu pelatihan, sarana dan prasarana, media pembelajaran, dan penilaian terhadap para tutor atau pemberi meteri pelatihan.

Berdasarkan hasil evaluasi terhadap pelaksanaan kegiatan menunjukkan bahwa sebagaian besar peserta menyatakan materi yang disampaikan sesuai dengan kebutuhan mereka di lapangan. Berkaitan dengan materi yang disampaikan mereka menyatakan bahwa materi kegiatan dapat menambah pengetahuan dan keterampilan mereka dalam memperoleh informasi yang baik dan benar. Hal ini disebabkan mereka belum pernah mengikuti pelatihan seperti ini.

\section{SIMPULAN}

Secara keseluruhan pelaksanaan PKM mengenai pelatihan literasi media kepada para guru PAUD di Kecamatan Cicalengka Kabupaten Bandung dapat meningkatkan kapasitas pengetahuan, pemahaman, keahlian, dan keterampilan para guru dalam memilih media sebagai sumber belajar yang baik dan benar. Selain itu, pelatihan ini dapat meningkatkan kemampuan para guru dalam mengembangkan program literasi media sebagai bentuk media pembelajaran.

\section{DAFTAR PUSTAKA}

Brophy, Peter. The Academic Library. $2^{\text {nd }}$ ed. London: Facet Publishing. 2005.
Cohen,Laura dan Jacobson, Trudi E. "Evaluation Web Content". University Library of Universi Albany. http://library.albany.edu/usered/eval/ evalweb/ . 25 Juni 2013

Creswell, John W. and Vicki L. Plano Clark. Designing and Conducting Mixed Methods Research. London: Sage Publications. 2007.

Cronin, Blaise and Elisabeth Davenport. Elements of Information Management. London: The Scarecrow Press. 1991.

Internet Corporation for Assigned Names and Numbers (http://www.icann.org). 27 Juni 2013

Pantry, Sheila and Peter Griffiths. Setting up a library and information service from scratch. London: Facet Publishing. 2005.

Pendit, Putu Laxman. Penelitian Ilmu Perpustakaan dan Informasi: Sebuah Pengantar Diskusi Epistemologi dan Metodologi. Jakarta: JIPFSUI. 2003.

Pendit, Putu Laxman. Apa Yang Selama Ini Dikaji Ilmu Perpustakaan dan Informasi. Makalah Sebagai Bahan Diskusi Dengan Pengajar Jurusan Ilmu Perpustakaan dan Informasi Fikom Unpad Bandung. 2009.

Sulistyo-Basuki. Pengantar Ilmu Perpustakaan. Jakarta: Gramedia. 1993.

Wallace, Danny P. and Connie Van Fleet. Library Evaluation: a casebook and can-do guide. Colorado: Libraries Unlimited. 2001.

Pandia, Top 5 Semantic Search Engines, http://www. pandia.com/sew/1262-top-5-semantic-searchengines.html , 28 Juni 2010

UC Berkeley Library. "Evaluating Web Pages: Techniques to Apply \& Questions to Ask”. UC Berkeley - Teaching Library Internet Workshops. http://www.lib.berkeley.edu/TeachingLib/ Guides/Internet/Evaluate.html . 29 Juni 2010

University of Maryland University College- Library. "Search the Web \& Evaluate Web Resources". INFORMATION AND LIBRARY SERVICES. http:/www.umuc.edu/library/guides/ web.shtml 29 Juni 2010 